\title{
Pemanfaatan Animasi 2 Dimensi Model Infografik dalam Perancangan Video Iklan Layanan Masyarakat Tentang Pengolahan Sampah Rumah Tangga di Denpasar
}

\author{
I Made MarthanaYusa, S.Ds., M.Ds. ${ }^{1}$, I Putu Septian Saputra ${ }^{(2}$ \\ 1) Dosen Teknik Informatika, konsentrasi Desain Grafis Multimedia, STMIK STIKOM Indonesia, \\ Denpasar, Bali, Indonesia \\ made.marthana@gmail.com \\ 2) Mahasiswa Teknik Informatika, konsentrasi Desain Grafis Multimedia, STMIK STIKOM Indonesia \\ Denpasar, Bali, Indonesia \\ septiantokek13@gmail.com
}

\begin{abstract}
Abstrak-Sampah rumah tangga adalah sampah yang dihasilkan oleh kegiatan rumah tangga sehari-hari. Sampah rumah tangga yang diolah dengan cara yang tidak benar dapat menyebabkan berbagai masalah lingkungan dan kesehatan. Masyarakat dapat berpartisipasi untuk mengatasi permasalahan sampah rumah tangga dengan cara mengolah sampah rumah tangga masing-masing dengan metode 3R. Namun, menurut DKP Kota Denpasar, pengetahuan dan motivasi masyarakat tentang pengolahan sampah rumah tangga dinilai sangat kurang. Dalam penelitian ini dilakukan perancangan sebuah video iklan layanan masyarakat tentang pengolahan sampah rumah tangga berbasis animasi 2 dimensi. Animasi 2 dimensi, khususnya dengan model infografik memiliki potensi dalam menyampaikan hal yang rumit dengan cara yang lebih sederhana. Dari hasil penelitian tersebut didapatkan data bahwa masyarakat merespon dan menilai sangat baik video iklan layanan masyarakat berbasis animasi 2 dimensi tersebut, baik dari sudut pandang desain maupun penyampaian informasi tentang pengolahan sampah rumah tangga.
\end{abstract}

Kata kunci-Sampah Rumah Tangga, Animasi 2D, Infografik, Iklan Layanan Masyarakat.

\section{PENDAHULUAN}

Dengan banyaknya permasalahan lingkungan dan kesehatan yang disebabkan oleh sampah di kota Denpasar, diperlukan koordinasi antara DKP Kota Denpasar dan masyarakat kota Denpasar. DKP kota Denpasar sebagai fasilitator dan motivator dalam hal pengolahan sampah di kota Denpasar telah melakukan berbagai upaya dalam hal pengelolaan sampah. Mulai dari menambah sarana dan prasarana hingga pengadaan Bank Sampah. Namun, sampah yang berhasil diolah setiap harinya hanya 400 ton/hari dari total produksi sampah yang mencapai 650 ton/hari. Oleh sebab itu diperlukan partisipasi masyarakat kota Denpasar untuk turut serta mengolah sampah rumah tangga masing- masing. Menurut UU. No. 18 th. 2008 tentang pengolahan sampah dan PP. No. 81 th.2012 tentang pengelolaan sampah, telah dijelaskan bahwa masyarakat dapat ikut serta berpartisipasi dalam hal pengelolaan sampah rumah tangganya masing-masing dengan metode pengolahan sampah 3R. Namun sosialisasi tentang 3R oleh DKP kota Denpasar terbatas pada penyuluhan di seluruh Bale Banjar di kota Denpasar dengan media presentasi dan pemberian buku saku tentang profil DKP kota Denpasar. Melihat media sosialisasi saat ini, maka media sosialisasi yang dipilih adalah berupa video iklan layanan masyarakat berbasis animasi. Kelebihan video animasi dibanding media yang lain adalah dapat menyampaikan informasi/ hal yang rumit menjadi hal yang sederhana sehingga mudah untuk dijelaskan. Pengujian video iklan layanan masyarakat tersebut menggunakan metode kuisioner dengan model skala likert dengan pengambilan sampel sejumlah 30 orang dari masyarakat kota Denpasar yang dipilih secara acak, dan 1 orang dari pihak DKP kota Denpasar sebagai Narasumber. Pengujian yang dilakukan bertujuan untuk mengetahui tingkat keberhasilan penyampaian informasi melalui media iklan layanan masyarakat tersebut terhadap masyarakat kota Denpasar.

\section{LANDASAN TEORI}

\subsection{Video}

Video adalah teknologi pemrosesan sinyal elektronik mewakilkan gambar bergerak. Aplikasi umum dari teknologi video adalah televisi, tetapi dia dapat juga digunakan dalam aplikasi teknik, saintifik, produksi dan keamanan [1].

\subsection{Iklan Layanan Masyarakat}

Iklan layanan masyarakat adalah jenis iklan yang bertujuan menyampaikan informasi atau pesan kepada masyarakat, tanpa mengharapkan keuntungan finansial[2]. 


\subsection{Pengolahan Sampah Rumah Tangga}

Dalam Undang-undang nomor 2008 tentang pengelolaan sampah[3] dijelaskan metode 3R sebagai berikut :

1. Pembatasan (Reduce)

Mengupayakan agar limbah yang dihasilkan sesedikit mungkin.

a. Memilih produk dengan kemasan yang dapat didaur ulang.

b. Hindari memakai dan membeli produk yang menghasilkan sampah dalam jumlah besar.

c. Menggunakan produk yang dapat diisi ulang (refill).

d. Menghindari penggunaan bahan sekali pakai.

2. Penggunaan Kembali (Reuse)

Bila limbah akhirnya terbentuk, maka upayakan memanfaatkan limbah tersebut secara langsung.

a. Memilih wadah, kantong atau benda yang dapat digunakan beberapa kali atau berulang-ulang.

b. Menggunakan alat penyimpan elektronik yang dapat dihapus dan ditulis kembali.

c. Menggunakan kertas bekas untuk keperluan lain.

3. Pendaur-ulangan (Recycling)

Residu atau limbah yang tersisa atau tidak dapat dimanfaatkan secara langsung, kemudian diproses atau diolah untuk dapat dimanfaatkan, baik sebagai bahan baku maupun sebagai sumber energi.

a. Memilih produk dengan kemasan yang dapat didaur ulang dengan mudah/terurai.

b. Mengolah sampah kertas menjadi karton.

c. Melakukan pengolahan sampah organik menjadi kompos.

d. Pengolahan sampah non-organik menjadi barang yang bermanfaat dan bahkan memiliki nilai jual.

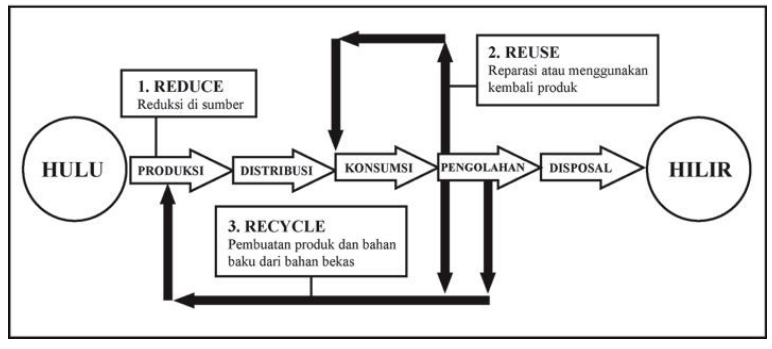

Gambar 1. Konsep Pengolahan Sampah Rumah Tangga Dengan Metode 3R

\subsection{Animasi}

Animasi adalah serangkaian gambar yang bergerak dengan cepat secara continue yang memiliki hubungan antara satu dan lainnya.[4]. Animasi komputer adalah seni membuat gambar bergerak dengan menggunakan komputer. Animasi komputer pada dasarnya menjadi pengganti animasi stop motion 3D dan animasi frame by frame 2 dimensi. Model animasi 2 dimensi dibuat dan/atau diedit di komputer menggunakan gambar bitmap atau gambar vektor 2 dimensi[5].

\subsection{Warna}

Warna sangat besar pengaruhnya dalam kehidupan manusia sehari-hari, baik dalam seni lukis, media massa cetak, desain interior, dll. Warna adalah hal yang pertama dilihat oleh seseorang. Dalam komunikasi grafis, penggunaan warna perlu ditata dan disusun dengan tepat sehingga menimbulkan suasana, mempengaruhi luas kehidupan manusia sekaligus sebagai lambang psikologis[6].

\subsection{Tipografi}

Tipografi (typography) adalah ilmu yang mempelajari tentang huruf[7]. Tipografi atau typography dapat memiliki pengertian luas yang meliputi penataan dan pola halaman, atau setiap barang cetak. Atau dalam pengertian lebih sempit hanya meliputi pemilihan, penataan dan berbagai hal bertalian pengaturan baris-baris susun huruf (typeset), tidak termasuk ilustrasi dan unsur-unsur lain bukan susun huruf pada pada halaman cetak. Peran dari pada tipografi itu sendiri adalah untuk mengkomunikasikan ide atau informasi dari halaman tersebut ke pengamat. Tipografi sama dengan menata huruf yang merupakan unsur penting dalam sebuah karya desain komunikasi visual untuk mendukung terciptanya kesesuaian antara konsep dan komposisi karya[8].

\subsection{Skala Likert}

Merupakan teknik pengukuran sikap dimana subjek diminta untuk mengindikasikan tingkat kesetujuan atau ketidaksetujuan mereka terhadap masing-masing pernyataan. Skala Likert merupakan salah satu teknik pengukuran sikap yang paling sering digunakan dalam riset pemasaran. Dalam pembuatan skala likert, periset membuat beberapa pernyataan yang berhubungan dengan suatu isu atau objek, lalu subjek atau responden diminta untuk mengindikasikan tingkat kesetujuan atau ketidaksetujuan mereka terhadap masing masing pernyataan.Skala ini umumnya menggunakan lima angka penilaian, yaitu : (a) Sangat Setuju, (b) Setuju, (c) Tidak Berpendapat, (d) Tidak Setuju, (e) Sangat Tidak Setuju[9].

\section{ANALISIS DAN PERANCANGAN}

\subsection{Video Pembanding}

Dalam penelitian ini juga digunakan video iklan pembanding sebagai bahan pertimbangan dalam penentuan konsep animasi yang akan dibuat. Adapun video iklan pembanding yang digunakan adalah video iklan layanan masyarakat yang berjudul "Sistem Bank Sampah oleh DKP 
Kota Denpasar", dimana inti cerita dalam iklan yang berdurasi 58 detik tersebut mengajak masyarakat untuk ikut berpartisipasi menjaga agar lingkungan tetap bersih dan sehat dengan mengikuti program Bank Sampah. Hasil screenshoot dan penjelasan iklan layanan masyarakat tersebut diuraikan dalam Tabel 1 berikut.

\begin{tabular}{|c|c|c|}
\hline No. & Iklan animasi 2 dimensi & Keterangan \\
\hline 1 & & $\begin{array}{l}\text { Scene satu, diawal video } \\
\text { terdapat animasi karakter } \\
\text { manusia yang berjalan } \\
\text { menuju Bank Sampah. }\end{array}$ \\
\hline 2 & & $\begin{array}{c}\text { Scene dua, terdapat } \\
\text { infografis yang } \\
\text { menjelaskan bahwa } \\
\text { sampah dapat diubah } \\
\text { menjadi uang dengan } \\
\text { menukarkannya di Bank- } \\
\text { bank sampah yang } \\
\text { terdapat di kota } \\
\text { Denpasar. }\end{array}$ \\
\hline 3 & & $\begin{array}{l}\text { Scene tiga, terdapat } \\
\text { animasi yang } \\
\text { menjelaskan proses } \\
\text { sampah yang sudah } \\
\text { dikumpulkan diubah } \\
\text { menjadi energi alternatif } \\
\text { bagi masyarakat. }\end{array}$ \\
\hline 4 & & $\begin{array}{c}\text { Scene empat, seorang } \\
\text { staf DKP kota Denpasar } \\
\text { mengajak masyarakat } \\
\text { untuk ikut serta } \\
\text { berpartisipasi dalam } \\
\text { Program Bank Sampah. }\end{array}$ \\
\hline 5 & Dinas Kebersihan dan Pertamanan Kota Denpasar & $\begin{array}{c}\text { Scene lima (closing), } \\
\text { menampilkan logo kota } \\
\text { Denpasar. }\end{array}$ \\
\hline
\end{tabular}

Kelebihan dari video "Sistem Bank Sampah oleh DKP Kota Denpasar" tersebut adalah ilustrasi dan narasi menjelaskan 2 hal yang berbeda, sehingga tidak terjadi redudansi (perulangan) dalam penyampaian informasi. Selain itu, kelebihan pada video iklan layanan masyarakat tersebut adalah penggunaan animasi dengan prinsip animasi yang tepat, yaitu gerakan arcs pada adegan karakter manusia menuju Bank Sampah. Sedangkan kekurangan video tersebut adalah tidak ada penjelasan mengenai tindak lanjut terhadap sampah non-organik setelah dikumpulkan ke Bank Sampah.

Selain video animasi 2 dimensi tentang program Bank sampah, dalam penelitian ini juga menggunakan video iklan pembanding dengan format live action tentang pengelolaan sampah dengan metode 3R di kota Denpasar sebagai bahan pertimbangan untuk penentuan konsep animasi yang akan dibuat. Video live action yang berjudul "Iklan DKP Cenk Blonk" dengan durasi 60 detik ini mempunyai inti cerita yaitu mengajak masyarakat untuk ikut serta berpartisipasi dalam pengolahan sampah menggunakan metode $3 \mathrm{R}$ serta membuang sesuai jadwal yang sudah ditentukan oleh pemerintah yaitu pukul 17.00 WITA sampai pukul 19.00 WITA. Hasil screenshoot dan penjelasan iklan tersebut diuraikan dalam Tabel 2 berikut.

\begin{tabular}{|c|c|c|}
\hline No. & Iklan Animasi 2 dimensi & Keterangan \\
\hline 1 & & $\begin{array}{c}\text { Scene satu, menampilkan } \\
2 \text { karakter wayang, yaitu } \\
\text { Cenk yang menyapa } \\
\text { Blonk saat akan } \\
\text { membuang sampah, } \\
\text { tetapi Cenk menyuruh } \\
\text { Blonk agar mengolah } \\
\text { sampahnya. }\end{array}$ \\
\hline 2 & & $\begin{array}{c}\text { Scene dua, Cenk } \\
\text { menjelaskan kepada } \\
\text { Blonk mengenai sistem } \\
\text { pengolahan berbasis 3R. }\end{array}$ \\
\hline 3 & & $\begin{array}{c}\text { Scene tiga, Cenk } \\
\text { mengajak Blonk untuk } \\
\text { ikut serta mewujudkan } \\
\text { kota Denpasar yang } \\
\text { bersih dan hijau }\end{array}$ \\
\hline 4 & & $\begin{array}{l}\text { Scene empat, Dalang } \\
\text { dari grup wayang Cenk } \\
\text { Blonk menjelaskan } \\
\text { mengenai jadwal yang } \\
\text { telah ditetapkan oleh } \\
\text { pemerintah untuk } \\
\text { membuang sampah }\end{array}$ \\
\hline
\end{tabular}




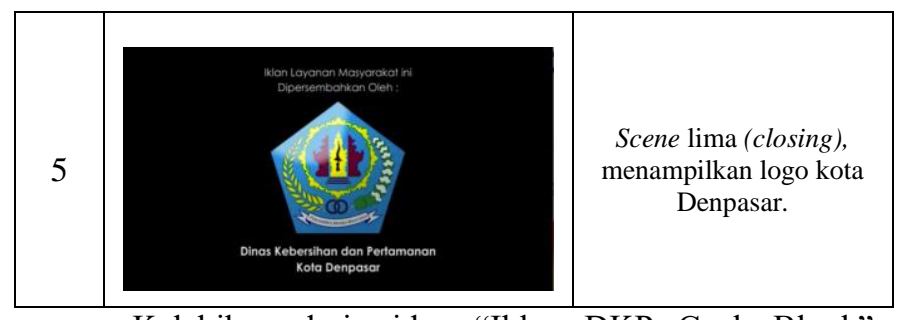

Kelebihan dari video "Iklan DKP Cenk Blonk" adalah alur cerita dan cara penyampaian yang jenaka dan ide yang unik, yaitu memakai permainan wayang tradisional Bali. Sedangkan kekurangan video tersebut adalah materi pesan yang terlalu banyak di dalam satu video iklan layanan masyarakat, yaitu mengajak masyarakat untuk menerapkan metode 3R, berhenti membuang sampah sembarangan, dan membuang sampah sesuai jadwal dan di tempat yang benar.

Dengan membandingkan kelebihan dan kekurangan dari ke 2 video iklan tersebut, didapatkan konsep perancangan video iklan layanan masyarakat yang akan dibuat yaitu menggunakan animasi 2 dimensi dengan aset berupa ilustrasi yang simpel dan narasi yang jelas sehingga memberikan kemudahan dalam memahami mengenai informasi yang akan disampaikan, yaitu tentang pengolahan sampah rumah tangga metode $3 \mathrm{R}$, dimulai dari penjelasan tentang masalah yang dihasilkan oleh sampah yang tidak dikelola dengan benar, berserta pertumbuhan volume sampah yang dihasilkan oleh masyarakat kota Denpasar dari tahun ke tahun, tahapan tata cara pemilahan sampah, penjelasan prosedur 3R, sampai jadwal pembuangan sampah sisa olahan yang telah ditetapkan oleh pemerintah. video tersebut nantinya mempunyai pesan inti untuk mengajak masyarakat berpartisipasi dalam pengelolaan sampah rumah tangganya masing-masing dengan menerapkan metode $3 R$ (Reduce, Reuse, Recycle).

\subsection{Metode Pengumpulan Data}

Data yang dikumpulkan untuk penyusunan laporan ini adalah data primer dan sekunder. Metode yang digunakan adalah sebagai berikut.

\subsubsection{Data Primer}

Data primer diperoleh melalui beberapa metode, yaitu metode observasi dan wawancara.

\section{Metode Observasi}

Observasi adalah teknik pengumpulan data yang diperoleh dengan cara melakukan pengamatan yang dilakukan secara langsung di lapangan. Pengamatan yang dilakukan adalah dengan melihat langsung bagaimana kesadaran masyarakat Denpasar tentang kebiasaan mereka dalam pengolahan sampah rumah tangganya masing-masing.

2. Metode Wawancara
Teknik pengumpulan data dengan interview atau wawancara merupakan teknik pengumpulan data dengan cara melakukan tanya jawab pada pihak lembaga-atau orang-orang yang terkait untuk mendapatkan informasi yang dibutuhkan.

Pada penelitian ini tim penulis melakukan wawancara menggunakan teknik wawancara terstruktur dengan tipe pertanyaan terbuka, yaitu penulis menanyakan beberapa pertanyaan langsung terkait dengan penelitian yang penulis sedang lakukan dengan memperlihatkan struktur dari pertanyaan yang diajukan. Penulis melakukan wawancara dengan Bapak Dr. I Dw Gd Anom Sayoga, MM selaku Sekretaris Dinas Kebersihan dan Pertamanan kota Denpasar. Bapak I Dr. I Dw Gd Anom Sayoga, MM dipilih sebagai narasumber karena beliau mengetahui dan dapat memberikan informasi-informasi yang dibutuhkan secara lengkap dan akurat mengenai materi yang dibahas.

Dalam wawancara tersebut tim penulis mengajukan beberapa pertanyaan yang berkaitan dengan penelitian yang sedang dilakukan oleh penulis. Dari hasil wawancara yang penulis lakukan, didapatkan informasi, saran dan pendapat mengenai sosialisasi yang akan penulis lakukan tentang pengolahan sampah menggunakan metode 3R di kota Denpasar. Bapak Dr. I Dw Gd Anom Sayoga, MM menjelaskan apa itu pengolahan sampah rumah tangga dengan metode $3 \mathrm{R}$ dan beberapa fakta aktual mengenai kendala atau masalah yang ada selama ini yang berkaitan dengan pengolahan sampah di kota Denpasar. Beliau juga menjelaskan apa saja yang dibutuhkan masyarakat kota Denpasar dalam pelaksanaan ke depannya jika video iklan layanan masyarakat ini dapat terlaksana.

\subsubsection{Data Sekunder}

Data sekunder diperoleh melalui beberapa metode, yaitu metode kepustakaan dan dokumentasi.

1. Metode Dokumentasi

Teknik dokumentasi merupakan teknik pengumpulan data dengan cara mengambil langsung data dan informasi berupa arsip-arsip pada Dinas Kebersihan dan Pertamanan (DKP) kota Denpasar. Data yang diperoleh dari DKP kota Denpasar berupa data timbulan sampah dan presentase komposisi sampah pada rentan waktu 2 tahun yaitu tahun 2012 dan tahun 2013. Selain itu penulis juga mengambil data berupa hasil dokumentasi media sosialisasi yang digunakan oleh DKP Kota Denpasar selama ini dalam hal penyelenggaraan pengolahan sampah ke masyarakat.

2. Metode Kepustakaan

Teknik studi pustaka merupakan teknik pengumpulan data yang bersifat teoritis yang diperoleh dengan melakukan studi pustaka atau membaca buku- 
buku, literatur yang ada hubungannya dengan permasalahan yang dibahas.

Teori yang digunakan dalam perancangan ini adalah teori mengenai video iklan layanan masyarakat dan animasi. Mulai dari proses perancangan hingga hasil akhir berupa video iklan layanan masyarakat animasi dua dimensi yang dijadikan acuan dalam perancangaan video iklan layanan masyarakat tentang pengolahan sampah rumah tangga berbasis animasi 2 Dimensi.

\subsection{Analisis Data}

Teknik analisis data merupakan cara menganalisis data penelitian, termasuk alat-alat statistik yang relevan untuk digunakan dalam penelitian.

\subsubsection{Penjabaran Hasil Pengumpulan Data}

Dalam Penyusunan laporan ini penulis melakukan penelitian ke Dinas Kebersihan dan Pertamanan (DKP) Kota Denpasar. Adapun penjabaran hasil pengumpulan data yang telah diperoleh adalah sebagai berikut.

1. Data Hasil Observasi

Data yang diperoleh dari hasil Observasi yang dilakukan di kota Denpasar adalah masyarakat kota Denpasar selama ini mengolah sampah rumah tangganya dengan cara yang berbeda-beda. Sebagian masyarakat di daerah pinggiran sungai dan drainase mengelola sampah rumah tangga mereka dengan cara membuangnya ke sungai maupun dibakar di pinggir sungai. Sebagian masyarakat di daerah yang dekat dengan TPS maupun kontainer DKP membuang sampah rumah tangganya di TPS dan kontainer tersebut tanpa memilah sampah organik dan non-organik. Sedangkan sebagian masyarakat dekat jalan raya mengelola sampah rumah tangganya dengan cara memilah antara sampah organik dan non-organik, dan menaruh sampah rumah tangga tersebut di depan gang maupun di pinggir jalan raya dengan tujuan agar diangkut oleh petugas DKP kota Denpasar pada jadwal yang telah ditentukan.

2. Data Hasil Wawancara dengan Sekretaris DKP kota Denpasar

Data yang diperoleh dengan metode wawancara dengan Bapak Dr. I Dw Gd Anom Sayoga, MM menyebutkan bahwa sampah yang dihasilkan masyarakat kota Denpasar tahun 2014 rata-rata per harinya mencapai $2700 \mathrm{M}^{3}$ atau setara dengan 650 ton per hari. Sedangkan daya olah dari 36 TPS (Tempat Pembuangan Sampah) dan Bank Sampah di Denpasar hanya 400 ton perhari, sehingga residu (sisa hasil buangan) yang belum diolah per harinya mencapai 250 ton per hari.

3. Data Hasil Dokumentasi

Data selanjutnya diperoleh dari hasil pengumpulan dokumentasi dari arsip-arsip yang ada di DKP kota
Denpasar. Volume sampah yang rata-rata diangkut oleh DKP kota Denpasar pada tahun 2012 per hari menurut jenisnya adalah $2703 \mathrm{M}^{3}$, yang terdiri dari 1297,44 $\mathrm{M}^{3}$ sampah organikdan 1405,56 $\mathrm{M}^{3}$ sampah Anorganik. sedangkan pada tahun 2013 mencapai 2938 M $^{3}$.

Tabel 3. Volume Sampah Terangkut Menurut Jenisnya

Tahun 2012-2013

\begin{tabular}{|c|c|c|c|}
\hline Tahun & Sampah Organik $\left(\mathbf{M}^{3}\right)$ & Sampah Anorganik $\left(\mathbf{M}^{3}\right)$ & Jumlah $\left(\mathbf{M}^{3}\right)$ \\
\hline 1 & 2 & 3 & 4 \\
\hline \hline 2012 & $1,297.44$ & $1,405.56$ & 2,703 \\
\hline & & & \\
2013 & $1,410.24$ & $1,527.76$ & 2,938 \\
\hline
\end{tabular}

Perkiraan produksi sampah oleh masyarakat kota Denpasar pada tahun 2012 adalah $3220 M^{3}$, yang terangkut sebesar $2703 \mathrm{M}^{3}$ sehingga presentase yang sampah yang terangkut terhadap sampah yang diproduksi adalah $83,94 \%$. Sedangkan produksi sampah oleh masyarakat pada tahun 2013 adalah $3500 \mathrm{M}^{3}$, yang terangkut sebesar $2938 \mathrm{M}^{3}$ sehingga presentase yang sampah yang terangkut terhadap sampah yang diproduksi adalah 83,94\%.

$1 \mathrm{v}$

Tabel 4. Volume Sampah Terangkut per hari Tahun 2012-2013

\begin{tabular}{|c|c|c|c|}
\hline Tahun & $\begin{array}{c}\text { Perkiraan Produksi Sampah } \\
\left(\mathbf{M}^{3}\right)\end{array}$ & Volume Sampah $\left(\mathbf{M}^{3}\right)$ & $\begin{array}{c}\text { Persentase Terangkut } \\
(\%)\end{array}$ \\
\hline 1 & 2 & 3 & 4 \\
\hline \hline 2012 & 3,220 & 2,703 & $83.94 \%$ \\
\hline 2013 & 3,500 & 2,938 & $83.94 \%$ \\
\hline
\end{tabular}

Asal sampah yang bersumber dari rumah tangga pada tahun 2012 sebesar $682140 \mathrm{M}^{3}$, dan pada tahun 2013 mencapai $909096 \mathrm{M}^{3}$.

Tabel 5. Volume Sampah Terangkut Menurut Asalnya Tahun 2012-2013

\begin{tabular}{|c|c|c|c|c|c|c|}
\hline No. & BULAN & $\begin{array}{c}\text { DKP KOTA } \\
\text { DENPASAR } \mathrm{m}^{3}\end{array}$ & PD. PASAR m ${ }^{3}$ & SWAKELOLA m ${ }^{3}$ & SWASTA $\mathrm{m}^{3}$ & JUMLAH \\
\hline 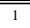 & JAANUARI & \begin{tabular}{ll|}
75,490 \\
\end{tabular} & 2,646 & \begin{tabular}{l|l|l}
3,980 \\
\end{tabular} & $\overline{6,112}$ & 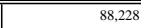 \\
\hline 2 & FEBRUARI & 68,173 & 2,490 & 3,804 & 5,366 & 79,833 \\
\hline 3 & MARET & 74,533 & 2,736 & 4,088 & 5,582 & 86,939 \\
\hline 4 & APRIL & 70,832 & 2,760 & 3,744 & $6,416.0000$ & 83,752 \\
\hline 5 & MEI & 73,131 & 2,916 & 3,980 & 6,816 & 86,843 \\
\hline 6 & JUNI & 71,716 & 2,760 & 3,954 & 6,822 & 85,252 \\
\hline 7 & JULI & 76,565 & 3,768 & 4,662 & 7,156 & 92,151 \\
\hline B.. & B.Q2stusAnali & sis Pengên & ipulan². & 4,080 & 6,592 & 90,809 \\
\hline $\begin{array}{c}9 \\
10\end{array}$ & ${ }_{\text {октове }}^{\text {SEPTEMвER }}$ Setel & dilagk & ana & ter,gar & dâtåta & yang ${ }_{94,339}^{89,351}$ \\
\hline $\mathrm{di}$ & Hapatkan & ernyata ${ }^{7} v^{201}$ & ume säm & pah darî. 5 tz & hun 201226 & ampai 92,851 \\
\hline tal & DESEMBER 13 & mengalanni & kenaiłant & dalam 3.546 & 8, & 99,960 \\
\hline ya & iftedsennenc & 235 & $\mathrm{~A}^{3}$, selati & itu asal & residu.51te & rsebut ${ }_{100.00} \%$ \\
\hline
\end{tabular}

sebagian besar berasal dari jenis sampah rumah tangga hal ini membuktikan bahwa pengolahan sampah dari rumah tangga atau tingkat produsen masih sangat kurang. 
Hasil wawancara menunjukkan bahwa media sosialisasi yang digunakan selama ini untuk mempromosikan program 3R di kota Denpasar hanya berupa penyuluhan di Bale Banjar dan 1 iklan live action di televisi. Iklan tersebut mempunyai kelemahan yaitu, bentuk promosi pengolahan sampah dengan metode 3R hanya berupa pengenalan, tidak membahas tahapan dan tata cara pengolahannya. Karena menurut Sekretaris DKP kota Denpasar, masyarakat selama ini hanya mengetahui dan belum memahami apa itu pengolahan sampah rumah tangga dengan metode $3 \mathrm{R}$, sehingga dampak yang diberikan adalah semakin meningkatnya volume sampah yang dihasilkan oleh produsen awal (masyarakat umum) berupa sampah jenis sampah rumah tangga.

Selain itu media yang digunakan dalam penyuluhan hanya berupa buku saku yang didalamnya berisi materi berupa profil DKP kota Denpasar, dan sangat sedikit membahas mengenai pengolahan sampah di tingkat rumah tangga. Sehingga masyarakat cenderung tidak mengaplikasikan materi penyuluhan yang diberikan.

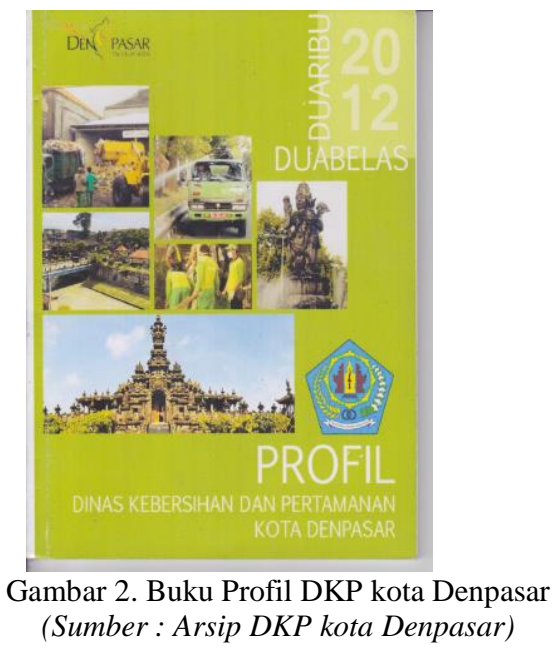

Dari hasil analisa dapat disimpulkan bahwa untuk mengenalkan kepada masyarakat tentang pengolahan sampah rumah tangga dengan metode 3R tidaklah cukup dengan hanya memberikan penyuluhan dan lewat bahan bacaan konvensional saja, akan tetapi harus ada media alternatif yang mampu menarik minat masyarakat untuk belajar memahami dan pengaplikasikan tentang pengolahan sampah rumah tangga dengan metode $3 \mathrm{R}$. berdasarkan hal tersebut, maka dipandang perlu untuk membuat iklan layanan masyarakat berupa animasi 2 dimensi berdasarkan kebutuhan masyarakat yang telah di dapat dari hasil wawancara dan dokumentasi.

\subsection{Konsep Perancangan}

Penulis menggolongkan video iklan layanan masyarakat tersebut bersifat sosial-non komersil. Digolongkan sosial karena memberikan informasi tata cara pengelolaan sampah demi kepentingan lingkungan masyarakat kota Denpasar sendiri. Digolongkan non-komersial karena tidak mengambil keuntungan secara komersial. Konsep perancangan ini disusun dalam sebuah skema yang bisa dilihat pada Gambar 2.

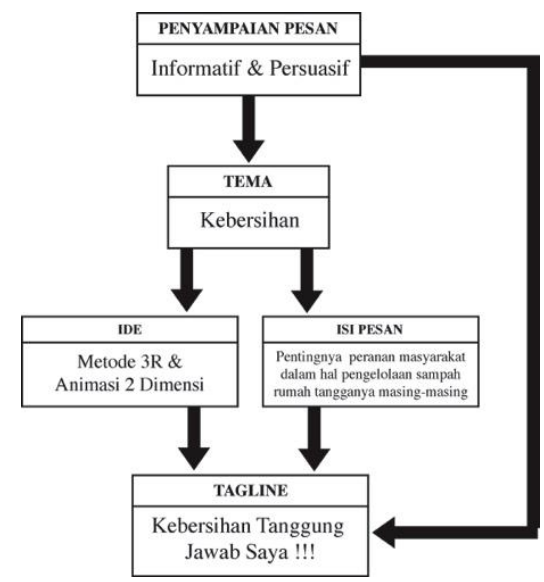

Gambar 3. Skema Konsep Perancangan

\subsection{Strategi Visual}

Dalam eksekusi desain iklan layanan masyarakat tentang pengelolaan sampah rumah tangga berbasis animasi 2 dimensi ini tidak terlepas dari unsur-unsur visual, berikut adalah implementasi unsur-unsur visual tersebut:

1. Ilustrasi

Ilustrasi yang digunakan dalam video iklan layanan masyarakat tersebut adalah ilustrasi jenis vektor yang sederhana.

2. Warna

Warna yang akan digunakan dalam pembuatan video tersebut adalah Warna Primer, Sekunder, dan Tersier sesuai dengan definisinya. Selain itu, dalam video iklan layanan masyarakat tersebut akan digunakan juga warna utama yaitu hijau, dengan pertimbangan hijau memiliki definisi dalam psikologi warna sebagai warna yang natural, lambang alam, dan kesejukan. Selain itu warna hijau merupakan warna seragam dan truk yang digunakan oleh petugas DKP kota Denpasar.

\section{Tipografi}

Tipografi yang digunakan adalah jenis font serif dan san-serif yang edible atau yang mudah dibaca, jelas dan terkesan elegan seperti Roboto, Caslon, Helvetica dan Avenir. 
4. Animasi

Animasi pada iklan layanan masyarakat tersebut menggunakan teknik animasi tweening dan masking, transisi dan beberapa teknik pergerakan kamera.

5. Suara

Untuk backsound akan menggunakan musik instrumen dari band Depapepe dan untuk pembacaan narasi akan dilakukan oleh seorang pengisi suara (dubber) pria.

\subsection{Metode Evaluasi Hasil Perancangan}

Penelitian ini dilakukan dengan menggunakan pendekatan kualitatif. Hasil dari pengolahan data bertujuan untuk mengetahui tingkat kelayakan video iklan layanan masyarakat tentang pengolahan sampah rumah tangga berbasis animasi 2 dimensi untuk ditayangkan dan didistribusikan. Pernyataan yang diajukan berkaitan dengan hasil perancangan yaitu penyampaian informasi, tingkat pemahaman dan tampilan visual dalam video iklan layanan masyarakat tersebut. Adapun pertanyaan yang akan diajukan dipaparkan dalam tabel 1 berikut:

Tabel 6. Daftar Pernyataan Evaluasi Hasil Perancangan Video Iklan Layanan Masyarakat Tentang Pengolahan Sampah Rumah Tangga Berbasis Animasi 2 Dimensi

\begin{tabular}{|c|c|c|c|c|c|c|}
\hline No & Pernyataan & SS & S & $\mathrm{N}$ & $\mathrm{TS}$ & STS \\
\hline 1. & \begin{tabular}{lrr} 
Pesan & dan & informasi \\
tentang & \multicolumn{2}{c}{ pengelolaan } \\
sampah & rumah tangga \\
melalui & video iklan \\
layanan & masyarakat ini \\
sudah & tersampaikan \\
dengan baik. &
\end{tabular} & & & & & \\
\hline 2. & $\begin{array}{l}\text { Akibat dari pengelolaan } \\
\text { sampah rumah tangga yang } \\
\text { tidak benar terhadap } \\
\text { lingkungan } \\
\text { dipahami. }\end{array}$ & & & & & \\
\hline 3. & $\begin{array}{l}\text { Tata cara pengelolaan } \\
\text { sampah rumah tangga yang } \\
\text { benar dapat dipahami. }\end{array}$ & & & & & \\
\hline 4. & $\begin{array}{l}\text { Keuntungan yang didapat } \\
\text { dari pengelolaan sampah } \\
\text { rumah tangga yang benar } \\
\text { dapat dipahami. }\end{array}$ & & & & & \\
\hline 5. & $\begin{array}{l}\text { Video iklan layanan } \\
\text { masyarakat yang sudah } \\
\text { ditayangkan menarik untuk } \\
\text { ditonton. }\end{array}$ & & & & & \\
\hline 6. & $\begin{array}{lc}\text { Tampilan animasi saat } \\
\text { menonton video iklan } \\
\text { layanan manarakat } \\
\text { ditayangkan nyaman untuk } \\
\text { ditonton. }\end{array}$ & & & & & \\
\hline 7. & $\begin{array}{lr}\text { video iklan layanan } \\
\text { masyarakat } & \text { ini } \\
\text { direkomendasikan } & \text { untuk } \\
\text { terus ditayangkan } & \text { dan } \\
\text { didistribusikan. } & \\
\end{array}$ & & & & & \\
\hline
\end{tabular}

Daftar pernyataan tersebut akan ditujukan 30 subjek sampel yaitu warga kota Denpasar yang dipilih secara acak selain itu juga akan ditujukan 1 buah daftar pernyataan kepada Sekretaris DKP kota Denpasar sebagai penanggung jawab dan narasumber. Sedangkan teknik ukuran yang digunakan yaitu teknik Skala Likert atau skala sikap. Nilai dari masing masing variabel ditentukan pada tabel 2 berikut.

Tabel 7. Keterangan Bobot Interval

\begin{tabular}{|c|c|c|c|}
\hline No. & Jawaban & Keterangan & Nilai \\
\hline 1. & SS & Sangat Setuju & 5 \\
\hline 2. & S & Setuju & 4 \\
\hline 3. & N & Netral / Tidak Berpendapat & 3 \\
\hline 4. & TS & Tidak Setuju & 2 \\
\hline 5. & STS & Sangat Tidak Setuju & 1 \\
\hline
\end{tabular}

Penentuan acuan nilai ditentukan dengan cara pembagian total presentase dengan jumlah interval. Maka penentuan nilai tertinggi dan terendah yang akan didapatkan adalah sebagai berikut:

\begin{tabular}{|c|c|c|}
\hline$S S$ & $=5 \times 30=150$ & (Nilai Tertinggi) \\
\hline$S$ & $=4 \times 30=120$ & \\
\hline$N$ & $=3 \times 30=90$ & \\
\hline$T S$ & $=2 \times 30=60$ & \\
\hline STS & $=1 \times 30=30$ & (Nilai Terendah) \\
\hline
\end{tabular}

Setelah dilakukan pengukuran dengan menggunakan skala likert dan dilakukan tabulasi atas tanggapan responden, maka hasil tabulasi data tersebut dimasukkan dalam garis kontinum yang pengukurannya ditentukan dengan cara sebagai berikut:

Tabel 3. Garis Kontinum

\begin{tabular}{r|r|r|r|r|r|} 
& $\begin{array}{c}\text { Tidak } \\
\text { Baik }\end{array}$ & $\begin{array}{c}\text { Kurang } \\
\text { Baik }\end{array}$ & $\begin{array}{c}\text { Cukup } \\
\text { Baik }\end{array}$ & Baik & $\begin{array}{r}\text { Sangat } \\
\text { Baik }\end{array}$ \\
\hline 0,5 & 1 & 2 & 3 & 4 & y
\end{tabular}

Keterangan : $\quad y=$ Total Skor yang diperoleh

Skala kontinum di atas akan digunakan sebagai pedoman untuk menginterpretasi hasil penelitian untuk mengetahui apakah setiap dimensi dapat dikatakan dalam kategori tertentu sesuai dengan nilai rata-rata jawaban dari kuesioner yang telah diisi oleh responden.

\section{HASIL DAN EVALUASI}

\subsection{Visualisasi Video Animasi Final}

Video animasi terdiri dari 11 scene dan dieksekusi sesuai rancangan storyboard. Durasi total video animasi 
adalah 6 menit 9 detik (369 detik). Visualisasi video (tabel 4) yang ditampilkan adalah scene-scene utama yang menyampaikan pesan penting terkait pengelolaan sampah rumah tangga.

Tabel 8. Visualisasi Video Animasi

\begin{tabular}{|c|c|c|c|}
\hline Scene & Durasi & \multicolumn{2}{|l|}{ Visual } \\
\hline 01 & 3 detik & & $\begin{array}{l}\text { PAH } \\
\text { MAH } \\
\text { GGA }\end{array}$ \\
\hline \multicolumn{2}{|c|}{$\begin{array}{l}\text { Keterangan: } \\
\text { Intro Animasi }\end{array}$} & \multicolumn{2}{|c|}{$\begin{array}{l}\text { Aksi : } \\
\text { Tong Sampah mengeluarkan kertas dengan judul } \\
\text { "PENGELOLAAN SAMPAH RUMAH TANGGA" } \\
\text { Transisi : Iris Round } \\
\text { Kamera : Front View } \\
\text { Musik : Upbeat Ukulele }\end{array}$} \\
\hline $\begin{array}{l}\text { Scene } \\
03-c\end{array}$ & $\begin{array}{l}\text { Durasi : } \\
10 \\
\text { detik }\end{array}$ & \multicolumn{2}{|c|}{16 TITIK } \\
\hline \multicolumn{2}{|c|}{$\begin{array}{l}\text { Data } \\
\text { Pengantar : } \\
\text { Dampak Buruk } \\
\text { Sampah }\end{array}$} & \multicolumn{2}{|c|}{$\begin{array}{l}\text { Aksi : } \\
\text { Muncul siluet kota dan air, kemudian muncul } \\
\text { tulisan data titik banjir di kota Denpasar. } \\
\text { Transisi : Push Up } \\
\text { Kamera : Front View } \\
\text { Musik: Upbeat Ukulele }\end{array}$} \\
\hline $\begin{array}{l}\text { Scene } \\
05-a\end{array}$ & $\begin{array}{l}\text { Durasi : } \\
25 \\
\text { detik }\end{array}$ & & \\
\hline \multicolumn{2}{|c|}{$\begin{array}{l}\text { Informasi } \\
\text { tentang Sampah } \\
\text { Rumah Tangga }\end{array}$} & \multicolumn{2}{|c|}{$\begin{array}{l}\text { Aksi : } \\
\text { Muncul penjelasan tentang sampah rumah tangga } \\
\text { dan data sampah rumah tangga di kota } \\
\text { Denpasar. } \\
\text { Transisi : Push Left } \\
\text { Kamera : Front View } \\
\text { Musik: Upbeat Ukulele }\end{array}$} \\
\hline $\begin{array}{l}\text { Scene } \\
05-b\end{array}$ & $\begin{array}{l}\text { Durasi : } \\
25 \\
\text { detik }\end{array}$ & $\frac{\text { ORGANIK }}{1410 \mathrm{Min}}$ & 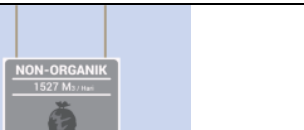 \\
\hline \multicolumn{2}{|c|}{$\begin{array}{l}\text { Komposisi } \\
\text { Sampah Rumah } \\
\text { Tangga }\end{array}$} & \multicolumn{2}{|c|}{$\begin{array}{l}\text { Aksi : } \\
\text { Layar terbagi } 2 \text { dan dimasing-masing panel layar } \\
\text { muncul ilustrasi sampah organik dan non-organik } \\
\text { dari arah berlawanan, kemudian muncul } \\
\text { keterangan data presentase sampah organik dan } \\
\text { non-organik dari sampah rumah tangga tersebut. } \\
\text { Transisi : Gauntlet Door } \\
\text { Kamera : Front View } \\
\text { Musik: Upbeat Ukulele }\end{array}$} \\
\hline
\end{tabular}

\begin{tabular}{|c|c|c|}
\hline $\begin{array}{l}\text { Scene } \\
08-a\end{array}$ & $\begin{array}{l}\text { Durasi : } \\
6 \text { detik }\end{array}$ & \\
\hline \multicolumn{2}{|c|}{$\begin{array}{l}\text { Solusi Pengolahan } \\
\text { Sampah Rumah } \\
\text { Tangga : disajikan } \\
\text { dalam } 5 \text { sub scene }\end{array}$} & $\begin{array}{l}\text { Aksi : } \\
\text { Tulisan } 3 \mathrm{R} \text { besar, muncul tulisan Reduce, Reuse, } \\
\text { Recycle. } \\
\text { Kamera : zoom out } \\
\text { Musik: Upbeat Ukulele }\end{array}$ \\
\hline $\begin{array}{l}\text { Scene } \\
11\end{array}$ & $\begin{array}{l}\text { Durasi : } \\
5 \text { detik }\end{array}$ & $\begin{array}{l}\text { KEBERSIHAN } \\
\text { TANGGUNG JAWAB }\end{array}$ \\
\hline \multicolumn{2}{|c|}{$\begin{array}{l}\text { Penutup : } \\
\text { slogan dan logo } \\
\text { Kota Denpasar }\end{array}$} & $\begin{array}{l}\text { Aksi : } \\
\text { Gulungan terbuka, di dalamnya berisi slogan } \\
\text { kebersihan kota Denpasar yang ketiga, yaitu } \\
\text { "Kebersihan tanggung jawab saya! } \\
\text { Transisi : Push Left } \\
\text { Kamera : Front View } \\
\text { Musik: Upbeat Ukulele }\end{array}$ \\
\hline
\end{tabular}

\subsection{Evaluasi}

Pengujian dilakukan untuk mengetahui tingkat keberhasilan video iklan layanan masyarakat ini untuk membantu masyarakat mengetahui tata cara pengolahan sampah rumah tangga dan memotivasi mereka untuk melakukan pengolahan sampah rumah tangga masingmasing. Pengujian dilakukan kepada masyarakat kota Denpasar. Responden berjumlah 30 orang, dipilih secara acak, dengan kulifikasi umur 18 sampai 40 tahun. Pengujian dilakukan dengan memberikan beberapa pernyataan melalui kuesioner.

Untuk mendapatkan hasil kualitatif, maka data harus diolah melalui rumus distribusi frekuensi. Distribusi frekuensi merupakan penataan data kualitatif. Bila data kualitatif dihitung dalam bentuk proporsi atau presentase, maka menjadi distribusi frekuensi relatif. Dengan distribusi frekuensi relatif, kita dapat mengetahui presentase suatu kelompok terhadap seluruh pengamatan. Perubahan data kualitatif menjadi presentase dilakukan dengan membagi frekuansi (f) dengan jumlah seluruh observasi (N) dan dikalikan 100. Secara matematis hal tersebut dapat ditulis dengan rumus sebagai berikut:

$$
P=\frac{f \times 100}{N}
$$

$$
\begin{array}{ll}
\text { Keterangan : } \\
\mathrm{P} & \text { : Presentase } \\
\mathrm{f} & \text { : Frekuensi / Jumlah } \\
\mathrm{N} & : \text { Jumlah Sampel }
\end{array}
$$

Setelah mendapatkan hasil pengukuran dengan skala likert maka akan dilakukan tabulasi kategori atas tanggapan sampel responden, dengan rumus sebagai berikut: 
ISSN 2087-2658

Jurnal Nasional Pendidikan Teknik Informatika (JANAPATI)

Volume 5, Nomor 1, Maret 2016

\begin{tabular}{ll} 
& \multicolumn{1}{c}{$\boldsymbol{K}=\boldsymbol{f} / \boldsymbol{N}$} \\
Keterangan & : \\
K & : Angka Kategori \\
f & : Jumlah Poin Likert \\
N & : Jumlah Sampel
\end{tabular}

Adapun data yang diperoleh dari hasil pengujian tersebut disajikan pada Tabel 4 berikut.

Tabel 9. Hasil Pengujian Video Iklan Layanan Masyarakat Tentang

Pengelolaan Sampah Rumah Tangga Berbasis Animasi 2 Dimensi

\begin{tabular}{|c|c|c|c|c|c|}
\hline No & Pernyataan & Jawaban & Jml & $\begin{array}{l}\text { Frek } \\
(\%)\end{array}$ & Poin \\
\hline \multirow{5}{*}{1} & \multirow{5}{*}{$\begin{array}{l}\text { Pesan dan } \\
\text { informasi tentang } \\
\text { pengolahan } \\
\text { sampah rumah } \\
\text { tangga melalui } \\
\text { video iklan } \\
\text { layanan } \\
\text { masyarakat ini } \\
\text { sudah } \\
\text { tersampaikan } \\
\text { dengan baik. }\end{array}$} & Sangat Setuju & 22 & $\begin{array}{c}73.3 \\
4\end{array}$ & 110 \\
\hline & & Setuju & 8 & $\begin{array}{c}26.6 \\
6\end{array}$ & 32 \\
\hline & & Netral & 0 & 0 & 0 \\
\hline & & Tidak Setuju & 0 & 0 & 0 \\
\hline & & Sangat Tidak Setuju & 0 & 0 & 0 \\
\hline \multicolumn{5}{|c|}{ JumlahPoin } & 142 \\
\hline \multicolumn{5}{|c|}{ JumlahPoinKategori } & 4.73 \\
\hline \multirow{5}{*}{2} & \multirow{5}{*}{$\begin{array}{l}\text { Akibat dari } \\
\text { pengolahan } \\
\text { sampah rumah } \\
\text { tangga yang tidak } \\
\text { benar terhadap } \\
\text { lingkungan dapat } \\
\text { dipahami }\end{array}$} & Sangat Setuju & 18 & 60 & 90 \\
\hline & & Setuju & 12 & 40 & 48 \\
\hline & & Netral & 0 & 0 & 0 \\
\hline & & Tidak Setuju & 0 & 0 & 0 \\
\hline & & Sangat Tidak Setuju & 0 & 0 & 0 \\
\hline \multirow{2}{*}{\multicolumn{5}{|c|}{$\begin{array}{c}\text { JumlahPoin } \\
\text { JumlahPoinKategori }\end{array}$}} & 138 \\
\hline \multicolumn{4}{|c|}{ JumlahPoinKategori } & & 4.60 \\
\hline \multirow{5}{*}{3} & \multirow{5}{*}{$\begin{array}{l}\text { Tata cara } \\
\text { pengolahan } \\
\text { sampah rumah } \\
\text { tangga yang benar } \\
\text { dapat dipahami. }\end{array}$} & Sangat Setuju & 17 & 56.6 & 85 \\
\hline & & Setuju & 13 & $\begin{array}{c}43.3 \\
3\end{array}$ & 52 \\
\hline & & Netral & 0 & 0 & 0 \\
\hline & & Tidak Setuju & 0 & 0 & 0 \\
\hline & & Sangat Tidak Setuju & 0 & 0 & 0 \\
\hline \multicolumn{5}{|c|}{ JumlahPoin } & 137 \\
\hline \multicolumn{5}{|c|}{ JumlahPoinKategori } & 4.57 \\
\hline \multirow{5}{*}{4} & \multirow{5}{*}{$\begin{array}{l}\text { Keuntungan yang } \\
\text { didapat dari } \\
\text { pengolahan } \\
\text { sampah rumah } \\
\text { tangga yang benar } \\
\text { dapat dipahami. }\end{array}$} & Sangat Setuju & 17 & 56.7 & 85 \\
\hline & & Setuju & 13 & 43.3 & 52 \\
\hline & & Netral & 0 & 0 & 0 \\
\hline & & Tidak Setuju & 0 & 0 & 0 \\
\hline & & Sangat Tidak Setuju & 0 & 0 & 0 \\
\hline & 137 \\
\hline \multicolumn{4}{|c|}{ JumlahPoinKategori } & & 4.57 \\
\hline No & Pernyataan & Jawaban & Jml & $\begin{array}{l}\text { Frek } \\
(\%)\end{array}$ & Poin \\
\hline \multirow{5}{*}{5} & \multirow{5}{*}{$\begin{array}{l}\text { Video iklan } \\
\text { layanan } \\
\text { masyarakat yang } \\
\text { sudah ditayangkan } \\
\text { menarik untuk } \\
\text { ditonton. }\end{array}$} & Sangat Setuju & 28 & 93.3 & 140 \\
\hline & & Setuju & 2 & 6.7 & 8 \\
\hline & & Netral & 0 & 0 & 0 \\
\hline & & TidakSetuju & 0 & 0 & 0 \\
\hline & & $\begin{array}{ll}\text { Sangat } & \text { Tidak } \\
\text { Setuju } & \\
\end{array}$ & 0 & 0 & 0 \\
\hline \multicolumn{5}{|c|}{ JumlahPoin } & 148 \\
\hline \multicolumn{5}{|c|}{ Jumlah Poin Kategori } & 4.93 \\
\hline 6 & Tampilan animasi & Sangat Setuju & 25 & 83.3 & 125 \\
\hline
\end{tabular}

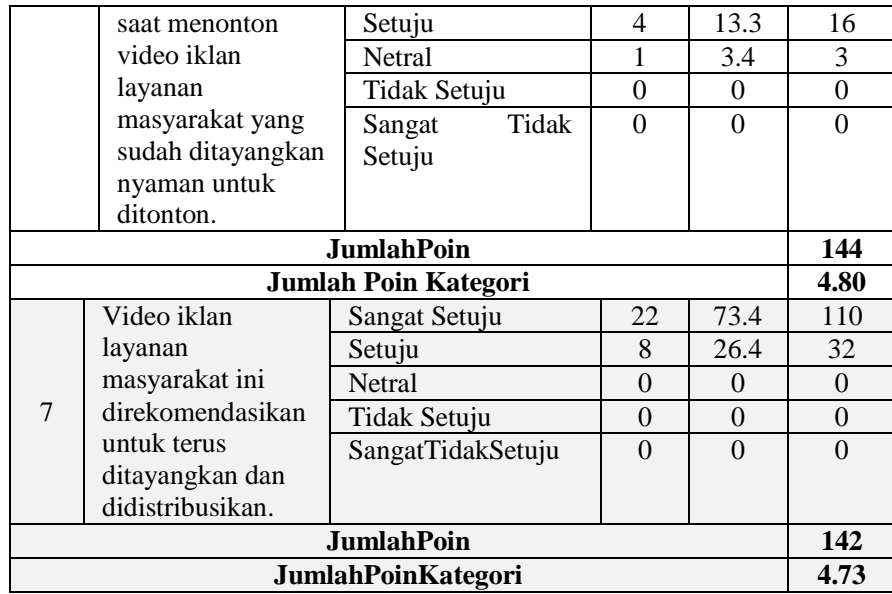

Hasil pengujian tersebut menunjukkan jumlah poin kategori yang berbeda untuk mendapatkan hasil berupa kategori. Maka hasil poin kategori pada tabel 4 harus dicocokkan dengan keterangan kategori. Adapun hasil kategori yang didapatkan dapat dilihat pada tabel 5 berikut:

\begin{tabular}{|c|c|c|c|}
\hline No & Pernyataan & $\begin{array}{c}\text { Poin } \\
\text { Kategori }\end{array}$ & Kategori \\
\hline 1. & $\begin{array}{l}\text { Pesan dan informasi tentang } \\
\text { pengelolaan sampah rumah } \\
\text { tangga melalui video iklan } \\
\text { layanan masyarakat ini sudah } \\
\text { tersampaikan dengan baik. }\end{array}$ & 4.73 & Sangat Baik \\
\hline 2. & $\begin{array}{l}\text { Akibat dari } \text { pengelolaan } \\
\text { sampah rumah tangga yang } \\
\text { tidak benar terhadap } \\
\text { lingkungan dapat dipahami. }\end{array}$ & 4.60 & Sangat Baik \\
\hline 3. & $\begin{array}{l}\text { Tata cara pengelolaan } \\
\text { sampah rumah tangga yang } \\
\text { benar dapat dipahami. }\end{array}$ & 4.57 & Sangat Baik \\
\hline 4. & $\begin{array}{l}\text { Keuntungan yang didapat } \\
\text { dari pengelolaan sampah } \\
\text { rumah tangga yang benar } \\
\text { dapat dipahami. }\end{array}$ & 4.57 & Sangat Baik \\
\hline 5. & \begin{tabular}{lcr}
\multicolumn{2}{l}{ Video iklan } & layanan \\
masyarakat yang & sudah \\
ditayangkan & menarik & untuk \\
ditonton. & & \\
\end{tabular} & 4.93 & Sangat Baik \\
\hline 6. & \begin{tabular}{lcr} 
Tampilan & animasi & saat \\
menonton & video & iklan \\
layanan & \multicolumn{2}{c}{ masyarakat } \\
ditayangkan & nyaman & untuk \\
ditonton. & & \\
ditont & &
\end{tabular} & 4.80 & Sangat Baik \\
\hline 7. & $\begin{array}{lr}\text { video iklan layanan } \\
\text { masyarakat } & \text { ini } \\
\text { direkomendasikan } & \text { untuk } \\
\text { terus ditayangkan } & \text { dan } \\
\text { didistribusikan. } & \end{array}$ & 4.73 & Sangat Baik \\
\hline
\end{tabular}

Berdasarkan paparan analisa tersebut di atas (tabel 5), dapat disimpulkan bahwa setelah video iklan layanan masyarakat tentang pengolahan sampah rumah tangga 
berbasis animasi 2 dimensi ini diujikan, hasil yang diperoleh adalah sesuai dengan harapan tim penulis. Video iklan layanan masyarakat ini telah berhasil memberikan informasi tentang pengolahan sampah rumah tangga untuk diterapkan dalam kehidupan sehari-hari.

\section{KESIMPULAN}

Berdasarkan paparan pembahasan, hasil dan evaluasi dapat dungkapkan beberapa hal sebagai kesimpulan. Berikut pemaparan kesimpulan:

1. Pembuatan iklan layanan masyarakat tentang pengolahan sampah rumah tangga berbasis animasi2 dimensi tersebut membutuhkan beberapa proses di lapangan yang meliputi proses pengumpulan data yang berhubungan dengan kebutuhan user. Setelah data diperoleh dan dianalisa barulah proses perancangan dimulai untuk mewujudkan media. Iklan ini dibuat dalam beberapa tahapan diantaranya praproduksi yang meliputi penterjemahan data, pembuatan naskah, narasi, dan sketsa storyboard. Proses produksi yang meliputi perekaman suara, pembuatan ilustrasi gambar aset, penganimasian. proses pasca produksi meliputi editing dan rendering video animasi.

2. Pengujian video animasi ini dilakukan dengan mengambil sampel 30 orang masyarakat kota Denpasar dengan kualifikasi umur 18-25 tahun secara acak. Pengujian dilakukan melalui kuesioner. Dari hasil pengujian didapatkan hasil bahwa seluruh informasi yang disampaikan melalui video iklan layanan masyarakat tersebut tersampaikan dengan baik, hal ini menunjukkan bahwa responden dapat mengetahui tentang pengolahan sampah rumah tangga melalui video iklan layanan masyarakat tersebut, sehingga dapat diterapkan untuk pengolahan sampah rumah tangga masing-masing individu sehari-harinya. Selain itu dari segi tampilan media didapatkan hasil bahwa desain video iklan layanan masyarakat tersebut sudah termasuk dalam kategori sangat baik menurut para responden.

\section{DAFTAR PUSTAKA}

[1] Manulang, Suwandi. 2004. "Video Profil Untuk Perusahaan". Jakarta : Grasindo.

[2] Supriyono, Rakhmat. 2010. "Desain Komunikasi VisualTeori dan Aplikasi". Yogyakarta: CV. Andi Offset

[3] Undang-undang Nomor 18 Tahun 2008 Tentang Pengolahan Sampah Rumah Tangga.

[4] Sugihartono, Ranang Agung. 2010. "Animasi Kartun : Dari Analog Sampai Digital". Jakarta : Indeks.

[5] Binanto, Iwan. 2010. "Multimedia Digital Dasar Teori dan Pengembangannya". Yogyakarta : Andi.

[6] Nugroho, Dr. Ir. Eko., M.Si. 2008. "Pengenalan Teori Warna". Yogyakarta: Andi.
[7] Hendratman, Hendi. 2008. "Tips dan Trik Komputer Desain Grafis". Bandung : Informatika.

[8] Santosa, Sigit. 2009. "Creative Advertising”. Jakarta : PT. Elex Media Komputindo.

[9] Noor, Dr. Juliansyah., SE., MM. 2013. "Metodologi Penelitian : Skripsi, Tesis, Disertasi dan Karya Ilmiah". Jakarta : Kencana Prenada Media Group.

\section{BIOGRAFI}

Penulis 1, I Made Marthana Yusa mendapatkan gelar S.Ds (Sarjana Desain) pada Fakultas Seni Rupa dan Desain (FSRD) di Institut Teknologi Bandung pada tahun 2006. Mendapatkan gelar M.Ds (Magister Desain) pada kampus yang sama, Pasca Sarjana FSRD, Institut Teknologi Bandung. Saat ini menjabat sebagai kepala Lembaga Penjaminan Mutu Internal dan staf pengajar pada Program Studi Teknik Informatika, konsentrasi Desain Grafis dan Multimedia STMIK STIKOM Indonesia (STIKI)

Nama lengkap penulis 2 yaitu I Putu Septian Saputra. Lahir di Denpasar, 20 September 1991. Adapun riwayat pendidikan penulis, yaitu pada tahun 2003 lulus dari SD Negeri 7 Dauh Puri. Kemudian melajutkan di SMP Negeri 4 Denpasar pada tahun 2003 sampai tahun 2006. Pada tahun 2009 lulus jurusan Pemanfaatan Ketenagalistrikan SMK Negeri 1 Denpasar. Pada tahun 2009-2010 melanjutkan kuliah Diploma 1 Jurusan Informasi Komputer di Wearnes Education Centre. Pada tahun 2011 melanjutkan kuliah di STMIK STIKOM Indonesia pada program studi Teknik Informatika Konsentrasi Desain Grafis dan Multimedia. Saat ini, Penulis 1 bersama dengan penulis 2 mendirikan dan mengembangkan start up bernama Imajilogi yang bergerak di bidang seni digital, animasi, game dan multimedia interaktif (imajilogi.com). 